\title{
Education is Our Best Future
}

\author{
J. T. Trevors • M. H. Saier Jr
}

Published online: 11 July 2008

(C) Springer Science + Business Media B.V. 2008

Education is required to insure a secure future for the world's citizens and our planet if humans are to succeed in preserving our common, shared, biosphere. Somehow, we must eliminate conflicts including but not restricted to war, terrorism, discrimination and racism. We must not allow religious differences to get in the way. Poverty and hunger fueled by greed and super-capitalism create breeding grounds for conflict of all types including terrorism. Economic globalization accompanied by resource depletion and unmanageable human population growth mean global disaster for all. Cooperation must be the means to the end if humankind is to survive.

We are already causing climate change and other forms of global pollution which will contribute to personal illnesses as well as pandemics of infectious diseases. Somehow we must eliminate these and other conditions that prolong human misery. Our common future must include education in every aspect of our lives. We must not be thinking only in terms of vocational education, but also in terms of social,

\footnotetext{
J. T. Trevors $(\bowtie)$

Department of Environmental Biology,

University of Guelph,

Guelph, ON, Canada N1G 2W1

e-mail: jtrevors@uoguelph.ca

M. H. Saier Jr

Division of Biological Sciences,

University of California, San Diego,

La Jolla, CA 92093-0116, USA

e-mail: msaier@ucsd.edu
}

political and moral education. Above all, the principles of tolerance, consideration and equality must be emphasized. There will be no quality future for humans without universal education at a level that will make everyone understand the severity of our problems and challenges. The world's people must be taught how these problems can best be solved and the urgency of this task. All must work towards their solutions.

We can not think of a single instance where people have achieved sustainability without proper comprehensive education. To solve our planetary problems, all the people of the world must be educated so that humanity can examine our problems from many different standpoints. The following areas will need attention:

The bare essentials include familiarity or knowledge of:

- the importance of birth control and it's use which must be available to all world citizens,

- basic literacy and math skills, a requirement for personal empowerment and rational evaluation,

- public health and disease transmission so that infectious diseases can be controlled,

- the importance of resource conservation for the preservation of our finite Earth.

We must teach the need for strict governance that prevents:

- child abuse and other forms of domestic violence that deprive people of their basic rights, 
- global pollution which threatens the health of the people and ecosystems upon which we all depend,

- exploitation of individuals or groups of people for the benefit of a few,

- substance abuse which can compromise one's physical and mental capabilities.

The educational system must also provide the tools that instill:

- tolerance of all belief systems while emphasizing rational thought and scientific evaluation,

- principles that allow people how to evolve modern equitable democracies,

- proper judiciary systems that are as unbiased and fair as possible,

- the need for cooperation and provision of forces that insure global peace and security as well as the execution of international law.

The system will also benefit if:

- teachers emphasize the global problems and how to identify and solve them,
- languages (and a possible universal language) are taught to facilitate communication,

- technologies of production, agriculture and environmental protection are used and developed to solve these problems rather than for personal gain, - basic scholarship becomes equitably available for all people in all disciplines.

If opponents argue this may prove to be too expensive, they should consider the cost of not implementing such an approach. Education provides the hope that people will act fairly without the use of force. The cost of not educating the people of the world is likely to be far greater than educating them. Education is the means to steer our human civilization in the correct direction so we have a common shared future. The alternatives are immense suffering, premature death, and a human population that the biosphere can not sustain. This would not be a future but a global disaster. One of the reasons we find ourselves in the present crisis is that politicians, and the militaryindustrial complex, are not the best qualified to understand and make the correct decisions. They simply do not have all the correct education and values. 